УДК 343.1

DOI https://doi.org/10.17308/vsu.proc.law.2021.1/3319

\title{
ПРИНУЖДЕНИЕ В СТАДИИ ВОЗБУЖДЕНИЯ УГОЛОВНОГО ДЕЛА
}

\author{
В. Ю. Стельмах \\ Уральский юридический институт МВД Российской Федераиии
}

Поступила в редакцию 25 марта 2020 г.

\begin{abstract}
Аннотация: анализируется возложность применения мер принуждения 8 стадии возбуждения уголовного дела. Аргулентируется недопустимость производства до возбуждения уголовного дела следственных действий, за исключениел тех, которые пряло разрешень уголовно-процессуальнылм законол. Констатируется также невозможность применения мер уголовно-процессуального принуждения. Приводятся доводь в пользу допустимости приленения дисииплинарных, административных и уголовно-правовых мер принуждения.

Ключевые слова: уголовное судопроизводство, возбуждение уголовного дела, процессуальное принуждение, адлинистративная ответственность, уголовнал ответственность.
\end{abstract}

\begin{abstract}
: the article analyzes the possibility of using coercive measures at the stage of criminal proceedings. The inadmissibility of proceedings prior to the initiation of criminal proceedings is argued, with the exception of those expressly authorized by criminal procedure law. It is also stated that it is impossible to use measures of criminal procedure. At the same time, arguments are made in favour of the admissibility of disciplinary, administrative and criminal coercive measures.
\end{abstract}

Key words: criminal proceedings, initiation of legal proceedings, procedural coercion, administrative responsibility, criminal liability.

- $\quad$ Российский уголовный процесс имеет стадию возбуждения уголовного дела, выполняющую роль фильтра, отделяющего преступные события от непреступных. Основной целью стадии возбуждения уголовного дела является установление оснований для возбуждения дела, т. е. достаточных данных, указывающих на наличие признаков состава преступления ${ }^{1}$.

Поскольку стадия возбуждения уголовного дела не может подменять собой полноценного расследования, она носит весьма краткосрочный характер (хотя в последнее время ее продолжительность с учетом возможных продлений сравнялась с дознанием в общей форме и стала превышать срок дознания в сокращенной форме) и располагает ограниченным арсеналом средств доказывания. В стадии возбуждения уголовного дела могут производиться не все следственные действия, а лишь те, которые прямо перечислены в уголовно-процессуальном законе. Следует отметить, что и этот перечень неуклонно расширяется законодателем, но при этом представляется недопустимым его увеличение на уровне толко-

${ }^{1}$ См.: Марковичева Е. В., Васюков В. Ф. Проблемные вопросы возбуждения уголовных дел на современном этапе. М., 2016. С. 12.

(C) Стельмах В. Ю., 2021 
вания закона, как это иногда происходит в практической деятельности, когда до возбуждения уголовного дела осуществляется выемка на основании того, что в ст. 144 Уголовно-процессуального кодекса Российской Федерации (далее - УПК РФ) закреплена возможность изъятия предметов и документов «в порядке, предусмотренном УПК РФ». Необходимо согласиться с авторами, полагающими, что аналогия закона в данном случае недопустима ${ }^{2}$, поскольку в результате ее применения происходит расширение принудительных мер, что противоречит общетеоретическим представлениям о границах аналогии уголовно-процессуального закона.

Одной из заметных отличительных особенностей стадии возбуждения уголовного дела является невозможность применения мер уголовно-процессуального принуждения. Это обусловлено самой природой рассматриваемой стадии. Поскольку до возбуждения дела само событие преступления считается неустановленным, меры процессуального принуждения не должны применяться.

Вместе с тем говорить о полном запрете принуждения в стадии возбуждения уголовного дела не приходится. Необходимость принуждения в этой стадии, как ни парадоксально, обусловлена также ее характером и предназначением. Выявление признаков преступления осуществляется в рамках познавательных процессов, которые, в свою очередь, организационно офрормляются в различные действия. З. З. Зинатуллин обоснованно отмечает, что в стадии возбуждения уголовного дела «осуществляется познавательная деятельность, в ходе которой предусмотренным законом способом получаются фрактические данные, используемые для обоснования доказываемого положения. Такая деятельность полностью подпадает под признаки доказывания как познания, осуществляемого в форме, предусмотренной уголовно-процессуальным законом, а ее результаты, то есть полученные фрактические данные, обладают нормативными признаками доказательства» ${ }^{3}$. Без надлежащей проверки сообщения невозможно принять законное решение о возбуждении уголовного дела, и допущенные на данном этапе нарушения могут повлечь существенные ограничения конституционных прав граждан ${ }^{4}$.

Нельзя согласиться с утверждением, согласно которому в стадии возбуждения уголовного дела (т. е. в рамках доследственной проверки) все действия проводятся исключительно добровольно. Во-первых, проверка сообщения о преступлении является публично-правовой деятельностью, по результатам которой принимается решение о возбуждении уголовного дела и тем самым запускается механизм полномасштабного осуществления уголовно-процессуальной деятельности. Во-вторых, поскольку

${ }^{2}$ См.: Азаренок Н. В. Особенности процессуального оформления добровольной выдачи предметов (документов) в стадии возбуждения уголовного дела // Уголовное право. 2018. № 3. С. 112-113.

3 Зинатуллин 3. З. Избранные труды : в 2 т. СПб., 2012. Т. 2. С. 57.

${ }^{4}$ См.: Варнавский Д. А. Способы проверки сообщения о преступлении // Рос. следователь. 2017. № 13. С. 7. 


\section{Вестник ВГУ. Серия: Право}

преступление является общественно опасным и запрещенным законом деянием, установление его обстоятельств не может не вызывать противодействия лиц, причастных к его совершению. В подобной ситуации проведение действий по установлению оснований для возбуждения уголовного дела исключительно на добровольных началах противоречит принципу публичности уголовного процесса и задачам стадии возбуждения уголовного дела. Таким образом, получение сведений, необходимых для принятия ключевого процессуального решения, ставится в зависимость от усмотрения конкретных лиц, а заинтересованные лица получают возможность блокировать и получение сведений, и тем самым - принятие решения о возбуждении уголовного дела.

Нельзя не заметить, что полная добровольность проводимых в стадии возбуждения уголовного дела действий противоречит современным тенденциям развития данной стадии. Законодатель, последовательно увеличивая сроки рассматриваемой стадии и наращивая количество допускаемых следственных и иных процессуальных действий, явно стремится придать стадии возбуждения уголовного дела задачу не только установления фракта преступления как такового, но и выявления определенных обстоятельств совершения преступного деяния.

Исходя из этого, правоприменитель в стадии возбуждения уголовного дела вынужден прибегать к принуждению. Возникает парадоксальная ситуация: при объективной необходимости принуждения ни одна уголовно-процессуальная принудительная мера в стадии возбуждения уголовного дела не предусмотрена. Это следует как из отсутствия в рассматриваемой стадии процессуального статуса у участвующих лиц, так и из того, что формулировки уголовно-процессуального закона прямо и однозначно устанавливают возможность применения процессуальных мер

- принуждения только после возбуждения дела.

Можно согласиться с невозможностью применения таких мер процессуального принуждения, как юридическое (уголовно-процессуальное) задержание подозреваемого, избрание мер пресечения, привод, временное отстранение от должности, наложение ареста на имущество. Применительно к этим мерам проблема намного глубже формального отсутствия процессуального статуса у субъектов, в отношении которых планируется избрать ту или иную меру. Невозможность применения названных мер обусловливается самой природой стадии возбуждения уголовного дела. Поскольку до принятия решения о возбуждении дела само преступное событие считается неустановленным и юридически неподтвержденным, невозможно говорить о придании кому бы то ни было процессуальных статусов, детерминированных фактическим отношением лица к преступному деянию. Соответственно, недопустимо подвергать тех или иных лиц ограничениям, вытекающим из данных статусов. Изменение данного подхода невозможно без коренной корректировки научных воззрений на стадию возбуждения уголовного дела.

Вместе с тем очевидна необходимость применения принудительных мер, напрямую не связанных с наличием у лица процессуального стату- 
са. Такие меры направлены на выявление преступления как такового, как фракта реальной действительности.

Выход из данной ситуации состоит в использовании так называемого непроцессуального принуждения. Отметим, что в настоящей статье не будет исследоваться вопрос законности и фрактического задержания, поскольку он представляет отдельную тему для изучения. Кроме того, в статье планируется сосредоточить внимание на деятельности следователя (дознавателя), осуществляющего процессуальные действия в рамках доследственной проверки.

Необходимо сразу уточнить используемую терминологию. Непроцессуальное принуждение в рассматриваемом контексте - это совокупность принудительных мер и механизмов, предусмотренных не уголовно-процессуальным законом, а иными законодательными актами. Непроцессуальное принуждение - это не произвол со стороны правоприменителя, не совершение им незаконных действий, а применение разрешенных законом принудительных мер. В этом смысле непроцессуальное принуждение по сфере отраслевого использования шире процессуального. Оно включает в себя те механизмы, право на применение которых принадлежит соответствующему субъекту в силу его государственно-властного статуса, который охватывает полномочия не только в сфере уголовного судопроизводства, но и в других законодательно регламентированных сферах деятельности ${ }^{5}$.

Принуждение включает в себя два обязательных элемента: обязанности субъекта и ответственность за их неисполнение. Отсутствие хотя бы одного из этих элементов делает механизм принуждения бездействующим.

Системный анализ законодательных актов позволяет выделить следующие виды непроцессуального принуждения, применение которых допустимо в стадии возбуждения уголовного дела.

Первый вид принуждения - это административно-правовые меры. В этом случае права правоприменительных органов, действующих в стадии возбуждения уголовного дела, соответствующие им обязанности других субъектов и меры ответственности за неисполнение этих обязанностей предусмотрены в законах, отнесенных к отрасли административного права. $К$ таким законам, в частности, относятся Федеральный закон «О полиции» и Кодекс Российской Федерации об административных правонарушениях (далее - КоАП РФ).

Федеральный закон «О полиции» регламентирует основные аспекты деятельности данного органа исполнительной власти и в силу этого имеет административно-правовую природу. Данный закон содержит общие, универсальные права полиции, реализуемые в любых сферах общественной деятельности, в частности вызывать в полицию граждан и должностных лищ; запрашивать и получать на безвозмездной основе сведения,

${ }^{5}$ См.: Булатов Б. Б. Государственное принуждение в уголовном судопроизводстве : дис. ... д-ра юрид. наук. Н. Новгород, 2003. С. 8. 


\section{Вестник ВГУ. Серия: Право}

справки, документы или их копии, иную информацию, в том числе персональные данные граждан; беспрепятственно посещать государственные и муниципальные органы, общественные объединения и организации, знакомиться с необходимыми документами и материалами; доставлять граждан в служебные помещения полиции; производить исследования и экспертизы объектов, истребовать для проведения экспертиз организаций независимо от форм собственности предоставление образцов и каталогов своей продукции, техническую и технологическую документацию и другие информационные материалы; производить осмотр транспортных средств и грузов; проверять места хранения, торговли, коллекционирования и экспонирования оружия, основных частей огнестрельного оружия (ч. 1 ст. 13 Федерального закона «О полиции»).

Нет каких-либо оснований ограничивать возможность применения положений данного закона сотрудниками полиции в стадии возбуждения уголовного дела, т. е. при проверке сообщений о преступлениях. Соответственно, корреспондируемые правами правоприменительного органа обязанности возникают у субъектов, не обязательно обладающих статусом участника уголовного судопроизводства.

КоАП РФ предусматривает административную ответственность за те или иные деяния, препятствующие осуществлению своих прав сотрудниками правоохранительных органов. Так, в ст. 17.7 КоАП РФ установлена ответственность за умышленное невыполнение законных требований следователя, дознавателя. Примечательно, что закон не говорит, что полномочия следователя и дознавателя возникают только в связи с производством по уголовному делу, что означает возможность распространения положений настоящей нормы КоАП РФ на доследственную проверку. Соответственно, если следователь либо дознаватель системы

- МВД России осуществляет свои процессуальные полномочия, реализуя права, предоставленные ему как сотруднику органов внутренних дел, ответственность соответствующих лиц за неисполнение требований следователя (дознавателя), вытекающих из ст. 13 Федерального закона «О полиции», может наступать по ст. 17.7 КоАП РФ.

Второй вид принуждения, применяемого в стадии возбуждения уголовного дела - это меры дисциплинарного характера. В ходе доследственной проверки субъект ее проведения обращается к различным органам, имеющим иерархическую внутреннюю структуру и при этом выступающим частью государственно-правового механизма. Очевидно, что в случае неисполнения работниками этих органов законных требований должностного лица, производящего доследственную проверку, последний вправе сообщить о фракте неисполнения руководству субъекта, не выполнившего требование.

Данный вид принуждения особенно актуален для субъектов, обязанных исполнять те или иные поручения следователей и дознавателей, например для сотрудников экспертно-криминалистических подразделений органов внутренних дел, которые обязаны производить не только судебные экспертизы, но и исследования в порядке исполнения служебного 
задания. За неполное, некачественное или несвоевременное проведение исследования не предусмотрено ни уголовной, ни административной ответственности, однако лицо, проводившее исследование, может быть привлечено к дисциплинарной ответственности за ненадлежащее исполнение своих прямых служебных обязанностей.

Следует учитывать, что требования должностного лица, проводящего доследственную проверку, должны соответствовать закону. Так, если изъятие определенных объектов допустимо только по судебному решению, это правило нельзя обойти, требуя предоставления объектов до возбуждения уголовного дела без решения суда, со ссылкой на то, что в ходе доследственной проверки получение судебного решения не предусмотрено уголовно-процессуальным законом. Такие аргументы нарушают причину и следствие. Закон, предусматривая необходимость получения судебного разрешения на изъятие того или иного объекта, исходит не из стадии уголовного судопроизводства, в которой происходит изъятие, а из содержания получаемых сведений. Исходя из этого, запрет получения той или иной информации без решения суда вызывается ее содержательными характеристиками и является универсальным, не зависящим ни от стадии уголовного судопроизводства, ни от наименования конкретного процессуального действия, посредством проведения которого осуществляется изъятие. Следовательно, требование предоставления подобных объектов без судебного решения, под угрозой привлечения за неисполнение этого требования к дисциплинарной ответственности, не основано на законе. Субъект, в распоряжении которого находятся объекты, в случае их передачи без судебного решения совершит правонарушение, а при некоторых условиях - даже уголовное преступление.

Третий вид принуждения, допускаемого в стадии возбуждения уголовного дела - это уголовная ответственность. Будучи самым строгим видом юридической ответственности, уголовная ответственность наступает только за деяния, прямо предусмотренные единственным нормативным актом - Уголовным кодексом Российской Федерации (далее - УК РФ). Запрещена аналогия уголовного закона, т. е. распространение ответственности на действия, сходные с запрещенными нормой УК РФ, но не включенными в объективную сторону данного состава преступления.

В настоящее время наиболее очевидной нормой, устанавливающей ответственность за действия в стадии возбуждения уголовного дела, является ст. 307 УК РФ. Объективной стороной предусмотренного ею состава преступления является дача заведомо ложных показаний и дача заведомо ложного заключения эксперта в досудебном производстве. Формулировка объективной стороны скорректирована, и теперь уголовный закон в качестве времени совершения преступления называет «досудебное производство». Данное понятие является уголовно-процессуальным, что обусловливает необходимость интерпретации нормы уголовного закона через уголовно-процессуальный понятийно-категориальный аппарат.

Соответственно возникает вопрос, возможно ли в настоящее время привлечение лица к уголовной ответственности за сообщение заведомо 
ложных сведений в ходе дачи объяснений. Представляется, что это невозможно, и измененная редакция ст. 307 УК РФ не распространяет свое действие на объяснения.

Как известно, досудебное производство в современном российском уголовном процессе включает в себя две стадии - возбуждение уголовного дела и предварительное расследование. При этом судебная экспертиза в силу прямого указания закона может быть назначена и произведена до возбуждения уголовного дела. Это означает, что рассматриваемое следственное действие может производиться как в стадии возбуждения уголовного дела, так и в стадии предварительного расследования. При этом очевидно, что порядок назначения и производства экспертизы должен быть одинаковым, поскольку в противном случае доказательственное значение экспертного заключения будет отличаться, что противоречит основополагающим правилам доказывания. Кроме того, процессуальный статус эксперта как участника уголовного судопроизводства приобретается лицом после поручения ему производства экспертизы. Соответственно, и до возбуждения уголовного дела, и после его возбуждения, лицо производит судебную экспертизу, обладая статусом эксперта. Объем полномочий и обязанностей эксперта не должен зависеть от того, назначена экспертиза до или после возбуждения уголовного дела. Соответственно эксперт подлежит уголовной ответственности за дачу заведомо ложного заключения независимо от того, производилась экспертиза до или после возбуждения уголовного дела. Это и фиксирует обновленная редакция ст. 307 УК РФ.

Вместе с тем показания - это сведения, сообщаемые лицом на допросе в процессуальном статусе свидетеля, потерпевшего, обвиняемого, подозреваемого, эксперта либо специалиста, или же в ходе очной ставки, яв-

- ляющейся разновидностью допроса. Производство допроса допускается только после возбуждения уголовного дела. Кроме того, придание лицу процессуального статуса свидетеля, потерпевшего, обвиняемого и подозреваемого возможно также исключительно после возбуждения дела. Исходя из этого, показания в процессуальном понимании этого термина в досудебном производстве могут быть получены лишь в стадии предварительного расследования.

Таким образом, ст. 307 УК РФ устанавливает уголовную ответственность за различные действия - дачу заведомо ложных показаний и заведомо ложного экспертного заключения в досудебном производстве, однако сами указанные действия могут производиться на различных стадиях досудебного производства. Производство экспертизы возможно в стадиях возбуждения уголовного дела и предварительного расследования, а дача показаний (т. е. допросы) - только в стадии предварительного расследования. Эти особенности следует учитывать при решении вопроса о привлечении лица к уголовной ответственности.

Кроме того, существуют особенности возникновения уголовной ответственности ряда субъектов, относящихся к должностным лицам. Так, если эксперт - криминалист органов внутренних дел, проводя до возбуж- 
дения уголовного дела исследование, заведомо неверно определит обстоятельства и даст заведомо ложные ответы на поставленные вопросы, что повлечет принятие незаконного решения о возбуждении уголовного дела или об отказе в возбуждении уголовного дела, привлечение данного сотрудника по ст. 307 УК РФ невозможно. Вместе с тем представляется, что имеются основания для привлечения лица к уголовной ответственности за должностное преступление. В зависимости от обстоятельств дела в действиях лица могут усматриваться: злоупотребление должностными полномочиями, превышение должностных полномочий, должностной подлог либо должностная халатность.

Уральский юридический институт Министерства внутренних дел Российской Федераиии

Стельмах В. Ю., кандидат юридических наук, доцент, профессор кафбедрь уголовного проиесса

E-mail:vlstelmah@mail.ru
Ural Legal Institute of the Russian Ministry of Internal Affairs

Stelmakh V. Yu., Candidate of Legal Sciences, Associate Professor, Professor of the Criminal Process Department

E-mail:vlstelmah@mail.ru 